\author{
양성 돌발성 두위 현훈 환자에서 \\ DHI(Dizziness Handicap Inventory)를 통한 \\ 주관적 어지럼의 이해 \\ 가톨릭대학교 의과대학 이비인후과학교실 \\ 박시내 · 조정해 · 박경호 - 채세용 - 남인철 - 박준욱 · 김명원 · 여상원
}

\title{
Understanding of Subjective Dizziness Using Dizziness Handicap Inventory in the Patients with Benign Paroxismal Positional Vertigo
}

Shi-Nae Park, MD, Jung-Hae Cho, MD, Kyung Ho Park, MD, Sayong Chae, MD, In-Chul Nam, MD, Jun Ook Park, MD, Myung Won Kim, MD and Sang Won Yeo, MD

Department of Otolaryngology-HNS, The Catholic University of Korea, College of Medicine, Seoul, Korea

\section{-ABSTRACT -}

Background and Objectives : The purposes of this study is to understand the self-perceived handicapping effect and the changes of dizziness after canalith repositioning (CRP) maneuver with mastoid percussion in the patients with benign paroxismal positional vertigo (BPPV) using dizziness handicap inventory (DHI). Materials and Method : A total of 83 patients with BPPV visiting the dizziness clinic of Kangnam St. Mary's Hospital from August, 2002 to July, 2003, were included in this study. DHI questionnaires, checked before and one week after CRP maneuver, were analyzed according to the type of BPPV. Result : The DHI scales of patients with posterior semicircular canal BPPV was $35.2 \pm 26.6,37.5 \pm 31.3$ with lateral semicircular canal BPPV and 70.0 \pm 36.8 with anterior canal BPPV. Especially, Most of the patients had higher scores in physical subscale than other subscales in DHI. Comparing the DHI scale change of before and after CRP maneuver, it made significant decrease in DHI scale after CRP maneuver from $37.1 \pm 27.0$ to $16.3 \pm 17.0$. Also all subscales of DHI, in other words, physical, functional, emotional factors, were decreased after CRP maneuver $(\mathrm{p}<0.01)$. Conclusion : In the patients with BPPV, self-perceived handicapping effects were mainly physical factors. DHI might be usefully applied to the patients with BPPV to understand their dizziness. (J Clinical Otolaryngol 2005;16:111-118)

KEY WORDS : Positional vertigo $\cdot$ Dizziness handicap inventory.

서 론

양성 돌발성 두위 현훈(Benign paroxysmal positional vertigo) 은 두위 변화에 따라 유발되는 짧은 기간의 현 훈이 돌발적으로 발생하는 말초성 전정 질환으로 1912 년 Barany 가 처음 기술하였고, 1952년 Dix 와 Hallpike

논문접수일 : 2005년 4월 6일

심사완료일 : 2005년 5월 13일

교신저자 : 여상원, 137- 701 서울 서초구 반포동 505번지 가톨릭대학교 의과대학 이비인후과학교실

전화 : (02) 590-1349. 전송 : (02) 595- 1354 E- mail : swyeo@ catholic.ac.kr 
가 양성 돌발성 두위 현훈이라고 명명하였고 안진을 유 발시키는 검사 수기와 안진의 특성을 자세히 기술한 바 있다.1) 체위 변화시에 안진의 방향은 이환된 반고리관과 이석의 위치에 따라 향지성 방향 변환성 안진과 향천성 방향 변환성 안진이 다양하게 나타날 수 있으며, 이환된 반고리관과 이석의 존재 위치, 즉, 반고리관 결석(canalith) 또는 팽대부릉 결석(cupulolith) 여부에 따라 다양 한 이석 정복술과 체위법 및 습관화 등의 전정 재활 치 료 방법들이 알려져 있다. ${ }^{2)}$ 이 중 이석 정복술의 기본 원 리는 반고리관 결석설( canalithiasis) 기전에 근거하여 반 고리관을 따라 머리의 위치를 변화시킴으로써 유동성 이 석을 공통각(common crus)으로 이동시켜 난형낭으로 빼내는 방법이고, 이석이 반고리관의 팽대부릉정에 붙어 발생되는 팽대부릉 결석설(cupulolithiasis) 의 경우에는 병변측 유양부에 진동기를 사용하여 반고리관 내 이석 으로 바꾼 후에 이석 정복술을 시행할 수 있다.

어지럼을 호소하는 환자를 관찰하는 방법으로 문진과 검사가 있지만, 환자 스스로 어지럼의 정도를 표기하는 설문지의 작성은 보다 짧은 시간동안 환자의 증상을 잘 이해하고 치료 효과를 판정하는데 도움을 줄 수 있다. 외 국문헌에서 많이 보고된 어지럼 설문지 중 하나인 Dizziness handicap inventory (DHI)는 전정 기관에서 유발 되는 현훈으로 인해 환자 스스로 생각하는 장애의 효과 정 도를 나타내기 위해 25가지 항목이 사용되고 있는데 기 능적, 감정적, 신체적 측면의 세 개 항목으로 이루어져 있 다. ${ }^{3)}$ 저자들은 양성 돌발성 두위 현훈 환자들을 대상으 로 한국어로 번역한 $\mathrm{DHI}$ 를 작성하게 하여 환자들이 느 끼는 주관적인 어지럼의 정도와 불편함을 이해하고 치료 전, 후의 변화를 관찰해 보고자 본 연구를 계획하였다.

\section{대상 및 방법}

\section{연구대상}

2002년 8월부터 2003년 7월까지 가톨릭대학교 의과 대학 부속 강남성모병원 이비인후과 현훈 클리닉에 내 원한 환자에서 Dix-Hallpike 수기와 앙와위에서 머리 를 좌, 우측으로 돌리는 갸웃 검사 Roll test) 와 같은 체 위성 검사 (positioning test) 를 통해 양성 돌발성 두위 현 훈의 진단 기준에 맞는 환자 83 명을 대상으로, 이들에 대
한 유양부 타진을 병행한 이석정복술의 치료 효과를 관 찰하였고, 이들 중 $\mathrm{DHI}$ 설문지 작성이 가능하였던 환자 들을 대상으로 DHI 설문지에 대한 분석을 하였다.

\section{방 법}

임상 양상 관찰 및 Dizziness handicap inventroy 측정 대상 환자들의 재발 빈도나 동반 내이 질환 등의 병력 을 기록하고 난청이 동반된 경우 청력 검사를 시행하였으 며, 동반 내이 질환에 따라 전기 안진 검사를 시행하기도 하였다. 환자들이 느끼는 불편함을 관찰하고자 치료 전과 치료 후 1주일째 한국어로 번역한 $\mathrm{DHI}$ 를 작성하게 하 였다. 번역된 DHI의 설문지(Table 1)는 항목별로" 예”, "때대로"," 아니오” 답변에 따라 각각 4점, 2점, 0점의 점수를 부과하여 총점은 0 100점으로 하였다.

유양부 타진을 병행한 이석 정복술

대상 환자들은 이환된 반고리관별로 이석 정복술을 시 도하였다. 뒤반고리관 반고리관 결석의 경우 Herdmann ${ }^{4)}$ 의 변형된 Epley 법을 이용한 이석 정복술을 시행하되 각 두위로 이동하는 동안 지속적으로 이환된 병변측의 유 양부를 가볍게 손으로 타진하는 방법을 사용하였다. 가쪽 반고리관과 앞반고리관 결석의 경우 각각 Barbecue 법 과 Reversed Epley 법을 이용하여 이석 정복술을 시도 하되 각 두위로의 이동시 유양부 타진을 역시 병행하였 다. ${ }^{45)}$ 팽대부릉 결석의 경우 안마기를 유양부에 대고 반 고리관 결석으로 전환 시킨 후 이석 정복술을 시행하였 다. 치료 직후 다시 해당 반고리관에 대한 체위성 검사 를 시행하여 만약 안진이 계속 관찰된다면 같은 이석 정 복술을 다시 시행하여 안진이 나타나지 않을 때까지 시 행 하였다. 증상이 사라진 후 1주 뒤 추적 관찰을 위해 내원한 환자에게 Dix- Hallpike 수기와 갸웃 검사를 다 시 시행하여 유리된 이석의 잔존 여부나 다른 반고리관 으로의 유입 여부를 확인하였고 안진이 재출현하여 불완 전한 정복을 보인다고 판단된 환자에게는 동일한 방법 으로 이석 정복술을 다시 시도하였고, 다시 1주 뒤 추적 관찰하였다. 추적 관찰시 체위성 검사를 시행하여 안진이 소실된 경우 이석 정복술이 성공적이었다고 평가하였다. 
박시내 외 : 양성 돌발성 두위 현훈 환자에서 DHI(Dizziness Handicap Inventory)를 통한 주관적 어지럼의 이해

Table 1. Korean version of Dizziness handicap inventory

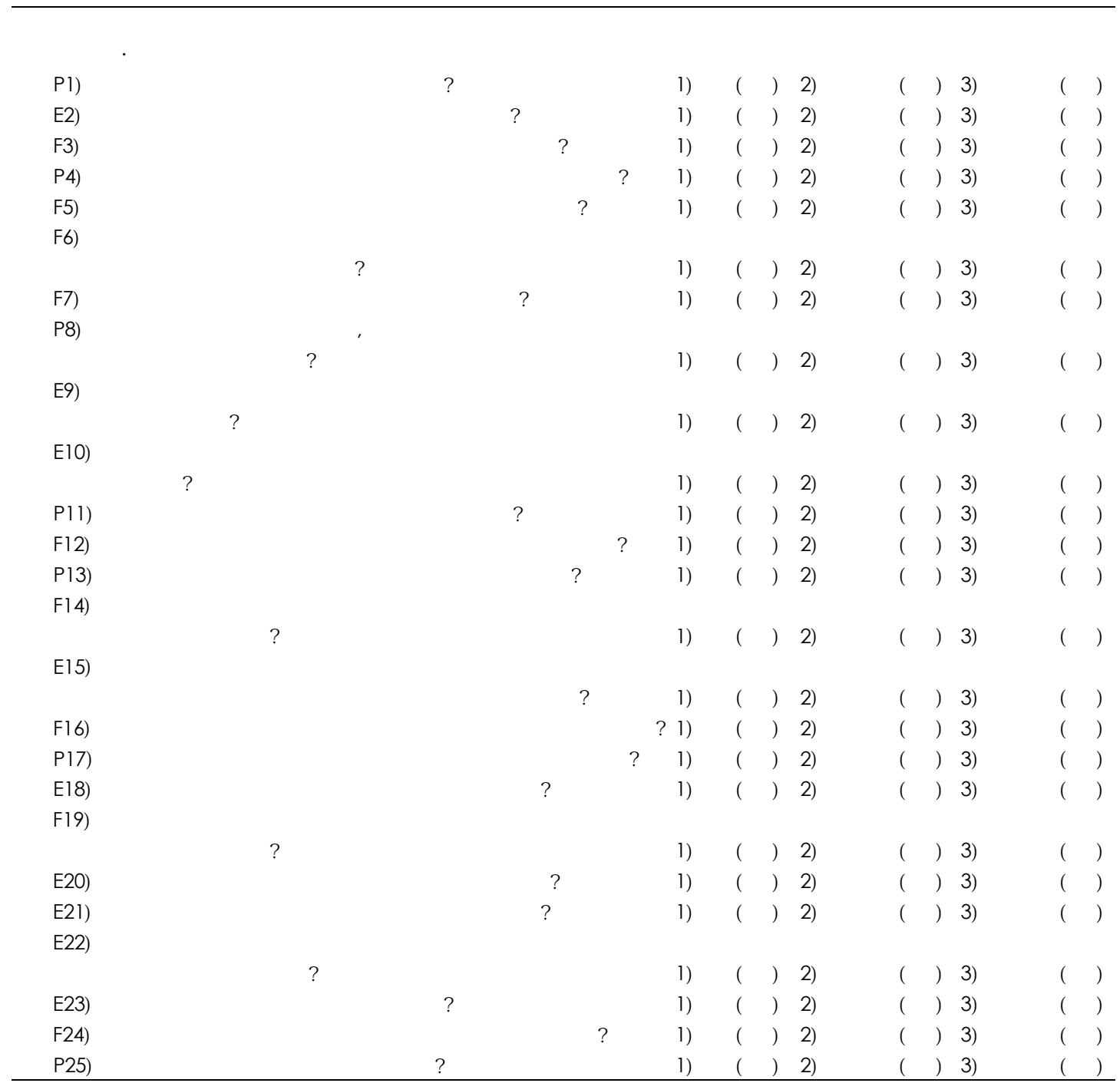

\section{통계적 분석}

통계적 분석은 SPSS(Version 11.5)를 통해 t- test 를 시행하였고 유의 수준 $p$ 값이 0.05 미만일 때 의미 있다고 판정 하였다.

\section{결 과}

\section{양성 돌발성 두위 현훈 환자의 임상 양상}

본 연구의 대상이 된 양성 돌발성 두위 현훈 환자 83

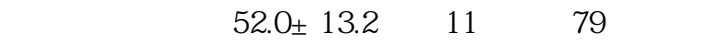
친 분포를 보이고 있었으며, 남녀 비는 $20: 63$ 으로 여 성에게서 현저히 많이 발생하였다. 이들 대상 환자에서 6 명의 환자는 두 개의 반고리관에 동시에 이환되어 있 었고, 89측의 이환 반고리관과 이석의 위치를 포함한 임상 양상을 분석한 결과, 좌측 : 우측 반고리관이 각각 $49: 40$ 비율로 이환되어 있었다. 이환된 전체 89측 반고 리관 중 55측(61.8\%) 에 해당하는 환자에서 뒤반고리관 의 반고리관 결석으로 진단되어 양성 돌발성 두위 현훈 
의 가장 많은 부분을 차지하고 있었으며, 23 측( $25.8 \%)$ 에서 가쪽반고리관의 반고리관 결석으로 두 번째로 흔 한 빈도로 발생함을 알 수 있었다. 또한 가쪽반고리관의 팽대부릉 결석을 보인 경우가 89 측 중 9 측 $(10.7 \%)$ 에 서 관찰되었고, 앞반고리관의 이환도 2 측 $2.3 \%$ )에서 발 생하였다. 두 개의 반고리관이 동시에 이환된 경우는 대 상 환자 83 명 중 7 명 $8.4 \%)$ 으로 이들은 모두 뒤반고 리관과 동측 가쪽반고리관의 반고리관 결석 양상을 띠 었다. 양성 돌발성 두위 현훈의 빈도를 관찰한 결과에서 는 대상 환자 83명 중 61 명 $73.5 \%$ ) 에서 내원시 첫 번 째 이환으로 조사되었으며, 18 명 $21.7 \%$ )은 두 번째 이 환으로, 4 명 $4.8 \%)$ 은 세 번째이상 이환된 병력을 호소 함으로써 대상 환자에서의 재발 빈도가 $26.5 \%$ 에 달하 였다. 이 질환과 관계되는 원인 혹은 동반 내이 질환을 관 찰한 결과, 대상 환자 중 2 명 $(2.3 \%)$ 은 전정신경염 직후 발생하였고, 4 명 $(4.8 \%)$ 은 메니에르병이나 재발성 전정질 환으로 추적관찰 중이던 환자에서 발생하였으며, 돌발성 난청에 동반된 환자도 4 명 $4.8 \%$ ) 에서 관찰되어 전체 환 자 중 10 명 $(12.0 \%)$ 의 양성 돌발성 두위 현훈환자에서 다른 내이 질환이 동반됨을 알 수 있었다. 또한 양성 돌 발성 두위 현훈 이환 직전 두부 외상의 병력은 7 명 $8.4 \%$ ) 의 환자에서 관찰되었다. 대상 환자들중 18 명에서 전기 온도안진검사를 시행하였다. 이들 중 5 명 $27.8 \%)$ 이 이 환측 귀에서 $20 \%$ 이상의 일측성 마비를 관찰할 수 있었 고, 그 중 4명이 선행된 전정신경염과 메니에르병, 재발 성 전정질환 등을 동반하고 있었다 (T able 2).

대상 환자들의 치료를 위해 증상이 소실될 때까지 시행 한 유양부 타진을 병행한 이석 정복술의 초기 시행 횟수 는 뒤반고리관에서 변형된 Epley 법을 시행한 경우 평균 $1.2 \pm 0.5$ 회, 가쪽반고리관에서 Barbecue법을 시행한 경 우 평균 $1.5 \pm 0.8$ 회였다. 1 주 후 추적 관찰시 증상이 있 어 초기 치료에 불완전한 이석 정복을 보였다고 판단되 는 환자는 4 명 $(4.8 \%)$ 이었기에 결국 초기 내원시 유양부 타진을 병행한 이석 정복술의 치료 효과는 $95.2 \%$ 에 해 당되었다. 불완전한 이석 정복으로 계속 증상이 있는 4 명의 환자에게는 이석 정복술을 다시 시행하고 1주 후 추 적 관찰하였으며, 그 결과 모든 환자에서 안진이 소실됨 을 관찰할 수 있었다. 가쪽반고리관 팽대부릉 결석으로 판단되는 9 명의 환자에서 안마기를 이용한 진동으로 반
Table 2. Clinical characteristics of the patients with benign paroxysmal positional vertigo ( $n=83$ )

\begin{tabular}{|c|c|c|}
\hline \multirow[t]{2}{*}{ Age } & Mean \pm SD & $52.0 \pm 13.2 y$ \\
\hline & Range & 11- $79 y$ \\
\hline \multicolumn{3}{|l|}{ Sex } \\
\hline & Male : Female & $20: 63$ \\
\hline \multicolumn{3}{|c|}{ Number of attacks } \\
\hline & $1 s t: 2 n d: 3 r d$ & $61: 18: 4$ \\
\hline \multicolumn{3}{|c|}{ Associated inner ear disorders } \\
\hline & Vestibular neuritis & $2(2.3 \%)$ \\
\hline & Meniere's disease & $2(2.3 \%)$ \\
\hline & Recurrent vestibulopathy & $2(2.3 \%)$ \\
\hline & Sudden deaf & $4(4.8 \%)$ \\
\hline \multicolumn{3}{|c|}{ Number of affected SCC } \\
\hline & Single : multiple & $77: 6$ \\
\hline \multicolumn{3}{|c|}{ Location of affected SCC ( $n=89)$} \\
\hline & Right : Left & $40: 49$ \\
\hline & Posterior SCC canalith & $55(61.8 \%)$ \\
\hline & Lateral SCC canalith & $23(25.8 \%)$ \\
\hline & Lateral SCC cupulolith & $9(10.7 \%)$ \\
\hline & Anterior SCC canalith & $2(2.3 \%)$ \\
\hline
\end{tabular}

고리관 이석으로 전환시킨 후 이석 정복술을 시행하였는 데 1 주후 추적 관찰시 모두 치료되었음을 확인하였다.

\section{이환 반고리관에 따른 $\mathrm{DHI}$ 상의 특성}

대상 환자 83명 중 치료 전에 DHI를 기록한 환자 55 명의 이환 반고리관에 따른 군별 $\mathrm{DHI}$ 특성을 관찰한 결 과, 뒤반고리관 반고리관 결석 환자군(37명) 에서 $\mathrm{DHI}$

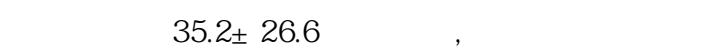
리관 결석 환자군(12명) 에서는 $37.5 \pm 31$.3점, 가쪽반고 리관 팽대부릉 결석 환자군(4명) 에서는 $30.5 \pm 15.4$ 점, 잎반고리관 반고리관 결석 환자군( 2 명) 에서는 $70.0 \pm 36.8$ 점을 보였다. DHI의 신체적(phy sical), 감정적(emotional), 기능적(functional) 측면에 따른 차이를 살펴본 결과에

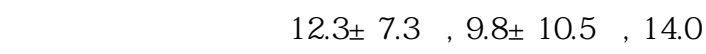
\pm 11 . 7점을 보였다. DHI 25개 항목 중 대상 환자들이 가장 많은 불편함을 호소하여 높은 평균점을 가진 항목 은 질문5(F5), 질문11(P11), 질문13(P13), 질문1(P1), 질문25(P25) 문항으로 5 개중 4 개가 신체적 측면의 불 편함을 나타내는 항목이었다 Fig. 1). 환자들이 주관적으 


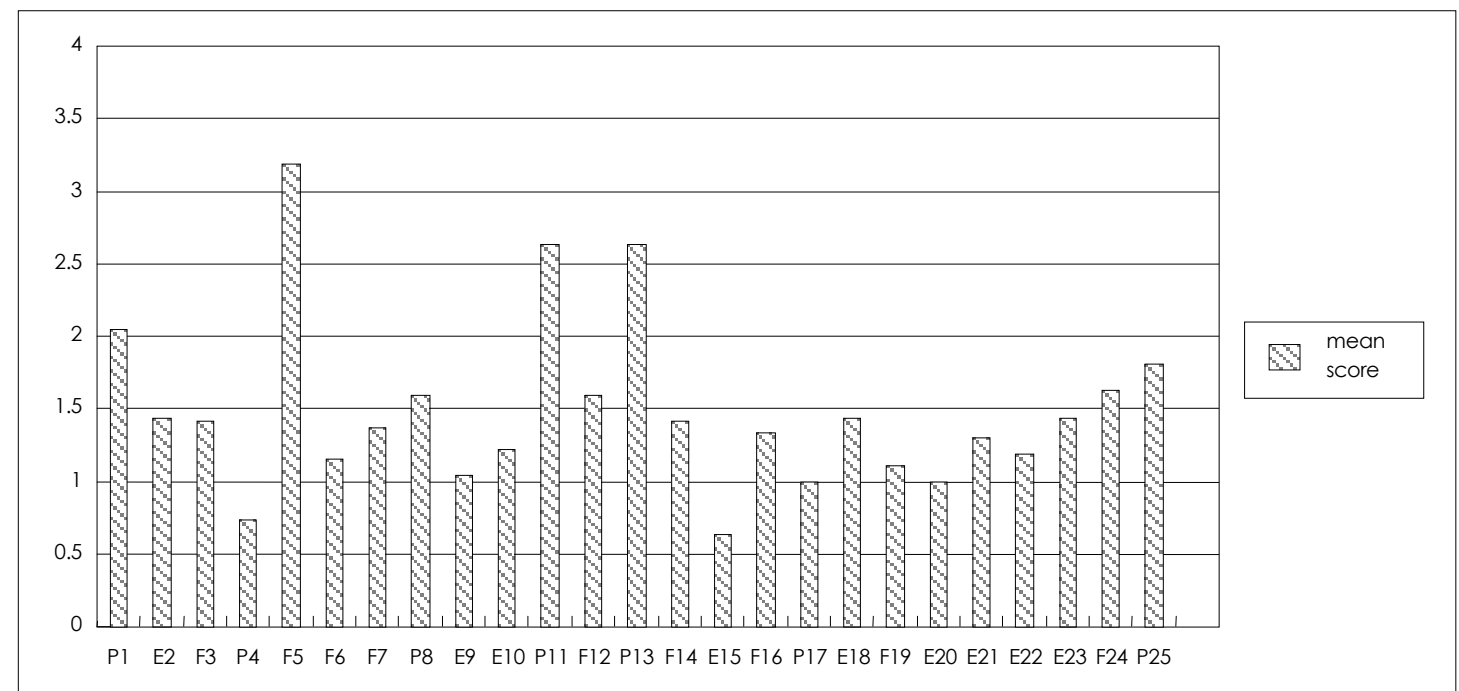

Fig. 1. Mean scores for each items of $\mathrm{DHI}$ in the patients with benign paroxismal positional vertigo before treatment.

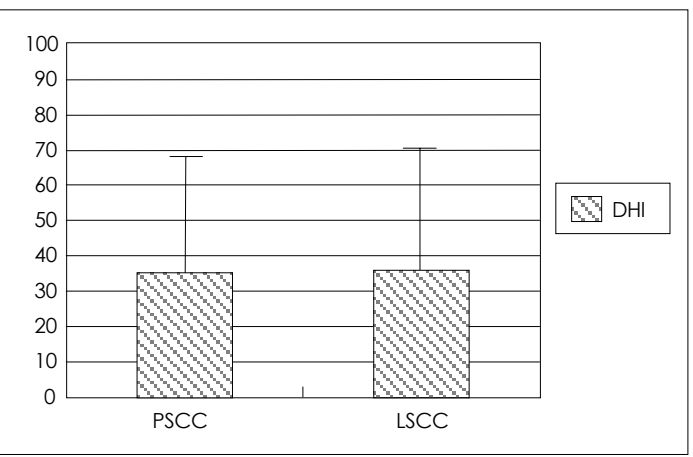

Fig. 2. Mean values of dizziness handicap inventory scores in the patients with posterior semicircular canal (PSCC) and lateral semicircular canal ( LSCC) BPPV show no significant difference ( $p>0.05)$. DHI : dizziness handicap inventory.

로 느끼는 불편함의 특성을 이환 반고리관 별로 이해하 고 통계적 의미를 살펴보기 위해 전체 환자의 $95 \%$ 이상 에 해당되는 뒤반고리관 반고리관 결석 환자군 $(n=37)$ 및 가쪽반고리관 반고리관 결석 환자군 $(n=16)$ 의 $\mathrm{DHI}$ 를 비교 분석한 결과, 이 두 군의 $\mathrm{DHI}$ 점수는 각각 평균 $35.2 \pm 26.6$ 점, 35.8 \pm 27.8 점으로 두 군간 의미 있는 차 이를 보이지 않았으며 $(p>0.05)$, 신체적, 기능적, 감정적 점수도 두 군간 의미 있는 차이를 보이지 않았다 $p>0.05$, Fig. 2) .

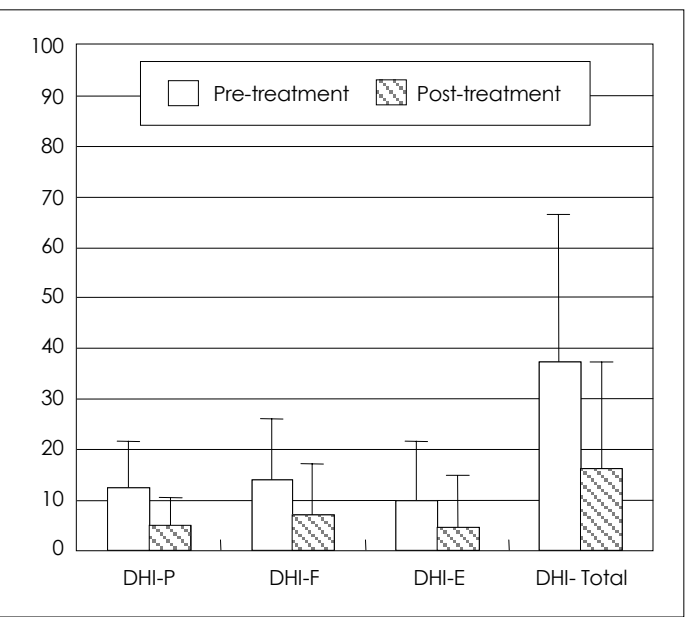

Fig. 3. Mean values of dizziness handicap inventory ( $\mathrm{DHI}$ ) scores at pre-treatment-Vs.- 1 week after treatment in the patients with benign paroxismal positional vertigo show significant differences in physical, functional, emotional, physical factors and total scores $(p<0.01)$. DHI$\mathrm{P}$ : dizziness handicap inventory-physical, DHI-F : dizziness handicap inventory-functional, DHI-E : dizziness handicap inventory-emotional.

\section{유양부 타진을 병행한 이석 정복술 치료 전, 후 $\mathrm{DHI}$ 의 변화}

본 연구의 대상 환자 중 이석 정복술 치료 전, 후에 모 두 $\mathrm{DHI}$ 를 작성하여 주관적 어지럼의 변화를 평가할 수 있었던 환자는 41 명이었으며, 이들의 치료 전, 후 $\mathrm{DHI}$ 변화를 관찰해 보았다. 전체 환자에서 치료전 $\mathrm{DHI}$ 값은 


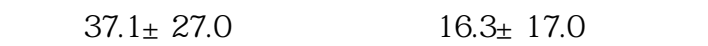
미있는 감소를 관찰할 수 있었다. DHI 신체적, 기능적, 감 정적 항목을 각각 살펴본 결과에서도 각 항목 모두 치료 후 의미 있게 감소하였다 ( $p<0.05$, Fig. 3).

\section{고 찰}

양성 돌발성 두위 현훈은 어떤 특별한 두위 시에 유발 되는 돌발적인 회전성 현훈이 수 초간 지속되는 재발성의 질환이지만 현재까지 본 질환으로 인한 장애나 환자들의 불편감에 대한 평가는 제대로 이루어지지 않고 있다. ${ }^{7)}$ 치 료시에 완치 판정은 안진의 유무, 증상의 소실, 장애 지수 (disability index)의 감소, $\mathrm{DHI}$ 등과 같은 설문 조사를 통해 판정할 수 있는데, 치료 시에 이석의 이동과 위치를 다시 확인하고 안진의 변화와 장애지수나 DHI와 같은 설문을 통해 임상증상의 변화를 고려하여 치료 전략을 수정하여야 한다. 본 연구에서는 양성 돌발성 두위 현훈 으로 진단된 환자들의 임상 양상을 살펴보고 본 병원에 서 시행하고 있는 유양부 타진을 병행한 이석 정복술을 소개하면서 치료 전, 후에 이들 환자에게 실시한 DHI 설 문지를 통한 환자의 주관적 장애 정도 이해와 그 결과를 토대로 양성 돌발성 두위 현훈 환자에 대한 DHI 설문지 의 임상적 가치를 살펴보고자 하였다.

대상 환자의 임상적 특성을 살펴본 결과, 대상 환자의 평균 연령이 52세로 기존의 보고에서 50 대가 가장 흔한 빈도로 발생하는 보고들과 비슷한 소견을 보였고, 남녀 비에서 본 연구에서는 여성이 남성에 비해 3 배 이상 높 은 빈도로 관찰되어 여성의 빈도가 높은 것은 일치하나 다른 보고들에 비해 성비차가 높았다.8 ${ }^{80}$ 본 연구에서 의 83명 환자에서 가장 많이 이환된 반고리관은 뒤반고 리관의 반고리관 결석으로 $61.6 \%$ 의 이환률을 보였고 그 다음으로 가쪽반고리관의 반고리관 결석이 $25.8 \%$ 로 흔 히 발생하는 소견을 보여 Rhee ${ }^{9}$ 가 국내 여러 기관에서 의 1,455 명을 대상으로 빈도 조사를 한 내용과 비슷한 소견을 보였다. 결국 본 연구 대상 양성 돌발성 두위 현 훈 환자의 이환 연령, 성비, 이환 반고리관의 분포는 기존 의 여러 보고와 큰 차이를 보이지 않음을 알 수 있었다. 두개 이상의 반고리관에 이환된 복합성 양성 돌발성 두 위 현훈도 약 $5 \sim 8 \%$ 의 빈도로 발생함이 보고된 바 있는
데, ${ }^{899}$ 본 연구에서도 두 개의 반고리관이 동시에 이환된 경우가 대상 환자 중 7 명 $8.4 \%)$ 으로 모두 뒤반고리관과 동측의 가쪽반고리관에 이환되었다. 양성 돌발성 두위 현 훈의 치료법으로 널리 인정되고 있는 이석 정복술은 1992 년 Epley에 의해 처음 제시 되었으며 뒤반고리관 반고리 관 결석으로 진단된 양성 돌발성 두위 현훈 환자에서 높 은 치료 성공률을 보이는 치료법으로 알려져 있다. ${ }^{11)}$ 가 쪽 반고리관 이석에 대한 이석 정복술로는 건강한 귀측 으로 90 도씩 체위 변환을 하여 360 도 바베큐식으로 돌 려서 이석을 정복시키는 Barbecue법이 대표적으로 알려 져 있다.5) 이석 정복술의 치료 횟수에 대한 보고로는 단 1 회씩만 이석 정복술을 시행하는 방법과 1회 방문시에 정해진 횟수만큼 이석 정복술을 시행하는 방법, 그리고 방문 시마다 어지럼증이나 안진이 소실될 때 까지 반복 적으로 시술하는 방법이 알려져 있다. ${ }^{12)}$ 본 연구에서는 대상 환자들의 치료를 위해 증상이 소실될 때까지 이석 정복술을 시행하였는데, 1 주 후 추적 관찰시 두위변환안 진이 관찰되어 초기 치료에 불완전한 이석환원을 보였다 고 판단되는 환자는 4 명 $4.8 \%)$ 으로 결국 초기 내원시 유양부 타진을 병행한 이석 정복술에 의한 치료 효과는 $95.2 \%$ 에 달하였다. 불완전한 이석 환원으로 증상이 다 시 관찰된 4명의 환자에게는 이석 정복술을 다시 시행 하고 1주후 추적 관찰하였으며, 그 결과 모든 환자에서 현훈과 안진이 소실됨을 관찰할 수 있었다. 가쪽반고리 관 팽대부릉 결석으로 진단된 9 명의 환자에서 안마기를 이용하여 반고리관 결석으로 전환시킨 후 이석 정복술 을 시행한 결과에서도 1주후 추적 관찰에서 완전 치유 가 되었음을 관찰할 수 있었다. 본 연구에서 시행한 유 양부 타진을 병행한 이석 정복술은 진동자를 사용하는 대 신 가볍게 유양부를 손으로 타진하는 방법을 사용하였는 데, 이 경우 특별한 기구를 필요로 하지 않으면서, 이석의 이동을 도울 수 있다는 진동자의 이치를 적절히 변형하여 활용하는 경우로 환자에게 특별한 불편함도 주지 않는 방법으로 양성 돌발성 두위 현훈 환자의 이석 정복술시 병행해 보는 것이 좋을 것으로 제안하는 바이다.

Jacobson과 Newman에 의해 처음 제시된 DHI는 전 정 기관의 장애에 의해 유발된 어지럼증에 대해서 환자 스 스로가 평가하는 주관적인 장애의 척도이다. ${ }^{3}$ 또한 $\mathrm{DHI}$ 는 치료를 계획하고 평가하는데 효과적인 정보를 제공하 
고 신뢰성이 있으며 환자가 기록하는 시간이 적게 걸리는 방법이면서 점수를 매기기가 쉬운 방법으로 알려져 있다. $\mathrm{DHI}$ 는 현재까지 국외 여러 보고에서 현훈의 약물 치료나 수술적 치료 및 전정 재활 치료의 효과를 평가하기 위한 수단으로 사용된 바 있다. 각각의 항목에 대해 환자들은 "예”," 아니오”," 때대로” 로 반응을 기록할 수 있으며 25 개의 항목 중에서 각각 9 가지의 기능적 측면과 감정적 측면, 그리고 7 가지의 신체적 측면을 나타내는 것으로 분류된다. 본 연구에서는 양성 돌발성 두위 현훈으로 진 단 된 환자에서 환자들이 느끼는 장애의 정도를 이해하 고, 유양부 타진을 병행한 이석 정복술의 효과를 평가하 기 위해 치료 전과 후에 각각 한국어로 번역된 $\mathrm{DHI}$ 를 기 록하게 하고 그 결과를 분석하였다. 결과, 치료전 환자 가 가장 불편함을 느끼는 것은 신체적 측면으로 대부분 이 두위 변환과 관련이 있었다. 즉 양성 돌발성 두위 현 훈의 전형적 임상 양상인 잠자리에서 돌아누울 때, 누웠 다 일어날 때 혹은 앉은 상태에서 누울 때 현훈을 느끼 는 것과 일치하여 이같은 신체의 체위 변화와 관련된 문항에서“ 예” 항목에 표시한 환자가 현저히 많음을 관 찰할 수 있었다. 이환된 반고리관에 따라 환자들이 느끼 는 주관적인 장애의 정도 차이를 관찰해 보고자 대상 환 자의 대부분인 뒤반고리관 결석 환자군과 가쪽 반고리 관 결석 환자군의 치료전 $\mathrm{DHI}$ 를 비교하여 보았다. 결과 적으로 두 군의 $\mathrm{DHI}$ 의 평균 점수와 신체적, 기능적, 감 정적 장애의 정도에서 유의한 차이를 보이지 않았는데, 이는 이환된 반고리관에 따른 환자의 주관적 장애 정도 에 큰 차이가 없다고 판단할 수 있는 소견이었다. 기존의 보고에서는 $\mathrm{DHI}$ 를 통한 설문 조사의 시간을 단축하고자 10 개의 설문 문항으로 구성 된 DHI- S(screening version of the dizziness handicap inventory) 를 이용하여 양성 돌발성 두위 현훈 환자에서 이석 정복술을 시행한 후 DHI- S 점수의 의미있는 감소를 보였다는 연구가 있 었으나, ${ }^{713)}$ 본 연구에서처럼 양성 돌발성 두위 현훈 치 료전 모든 항목에 대해 보다 구체적으로 환자가 느끼는 생활에서의 장애의 정도를 신체적, 기능적, 감정적 측면 으로 나누어 상세한 보고를 한 경우는 없었기에, 본 연 구 결과는 의미를 가진다고 생각하며, 양성 돌발성 두위 현훈 환자의 신체적 측면의 불편함을 $\mathrm{DHI}$ 설문지를 활 용해 쉽게 파악할 수 있다고 제안하는 바이다. 또한 어
지럼 환자의 진료전에 $\mathrm{DHI}$ 설문지를 작성하게 하고 신 체적 측면에서 높은 점수를 보일 경우 양성 돌발성 두 위 현훈으로의 진단적 접근에 도움을 받을 수 있을 것 으로 판단되며, 이같은 진단적 접근의 보다 객관적인 활 용을 위해서는 어지럼 질환별로 $\mathrm{DHI}$ 결과를 분석해 볼 필요가 있을 것이다. 또한 대상 환자 중 41 명에게는 이 석 정복술 전, 후의 $\mathrm{DHI}$ 결과를 비교해 보았는데, $\mathrm{DHI}$ 값이 치료 전에 비해 치료 후 의미 있게 감소함을 관찰 할 수 있었고 신체적, 기능적, 감정적 측면 모두에서 통 계적으로 유의하게 감소되어 치료 후 안진의 소실과 함 께 환자의 주관적 장애 정도를 평가함에 있어 $\mathrm{DHI}$ 가 유용하게 사용될 수 있다고 판단되었다.

\section{결 론}

본 연구를 통해서 $\mathrm{DHI}$ 설문 조사는 양성 돌발성 두 위 현훈 환자들이 가장 많이 느끼는 불편함, 즉 설문 내 용에서의 신체적 측면에 대한 이해를 도울 수 있었으며, 이들 환자의 주관적인 어지럼의 진단과 치료 효과 평가 에 적절히 활용될 수 있다고 생각한다. 더불어 다양한 어지럼 질환에 대한 $\mathrm{DHI}$ 결과를 비교 분석하는 추가적 연구도 가능할 것으로 생각한다.

중심 단어 : 체위성 현훈. DHI.

\section{REFERENCES}

1) Barany R. Diagnose von Krankheitsercheimtngen im Bereiche des Otolighenapparates. Acta Otolaryngol 1920;2: 434-7.

2) Jo SW, Jung WK. Effectiveness of Cupulolith repositioning maneuver in the treatment of lateral semicircular canal cupulolithiasis. Korean J Otolaryngol 2000;43:1147-57.

3) Jacobson P, Newman CW. The development of the dizziness handicap inventory. Arch Otolaryngol Head Neck Surg 1990;116:424-7.

4) Herdman SJ, Tusa RJ, Zee DS, Proctor LR, Mattox DE. Single treatment approaches to benign paroxysmal positional vertigo. Arch Otolaryngol 1993;119:450-4.

5) Fife TD. Recognition and management of horizontal canal benign paroxismal positional vertigo. Am J Otol 1998;19: 354-61.

6) Honrubia V, Baloh RW, Harris MR, Jacobson KM. Paroxysmal positional vertigo syndrome. Am J Otol 1999;20: 465-70.

7) Lopez-Escamez JA, Gomez Finana M, Fernandez A, Sanchez Canet I, Palma MJ, Rodriguez J. Evaluation of the 
J Clinical Otolaryngol 2005;16:111-118

treatment of benign paroxysmal positonal vertigo with the DHI-S questionnaire. Acta Otorrinolaringol Esp 2001;52: 660-6.

8) Katsarkas A, Kirkham TH. Paroxysmal positional vertigo-a study of 225 cases. J Otolaryngol 1978;7:320-30.

9) Rhee CK. Benign paroxysmal positional vertigo. Korean $J$ Otolaryngol 2004;47:491-506.

10) Marciano E, Marcelli V. Postural restrictions in labyrin- tholithiasis. Eur Arch Otorhinolaryngol 2002;259:262-8.

11) Epley JM. The canalith repositioning procedure. Otolaryngol Head Neck Surg 1992;107:399-404.

12) Macias JD, Lambert KM, Massingale S, Ellensohn A, Fritz JA. Variables affecting treatment in benign paroxysmal positional vertigo. Laryngoscope 2000;110:1921-4.

13) Jacobson GP, Calder JH. A screening version of the dizziness handicap inventory (DHI-S). Am J Otology 1998;19:804-8. 